\title{
Strategic Management and Firm Performance
}

\author{
Assoc. Prof. Dr. Sadudin Ibraimi \\ Faculty of Business and Economics, South-East European University, Ilinden 335, 1200 \\ Tetovo, North Macedonia
}

\begin{abstract}
:
This paper discusses the relationship between business strategies of firms and their performances. In the beginning the strategic aspects of the concept are presented, then competition and performance and their linkage to strategy is discussed. This is followed by the discussion of several empirical studies on the determinants of firm financial performance. Researches confirm that firms within the same industry differ from one another, and that there seems to be an inertia associated with these differences.
\end{abstract}

Keywords: Strategic management, planning, performance, competitive advantage

\section{Introduction}

Strategic planning departments, strategy consultants, and books and seminars on strategy have all flourished. But it was the 1980s during which strategy became a full-fledged management discipline. Many of the early tools and techniques of strategic planning were replaced by more sophisticated, more appropriate, and more actionable approaches. Strategic planning evolved from an art practiced by specialists to an accepted and integral part of all line managers. The result has been a downsizing of planning staff, but an upsizing of the significance of strategic planning in many organizations (Hisrich and Ramadani, 2017; 2018).

The advances in strategic planning could not have come at a better time. Companies all over the world face growing competition, both at home and abroad, as trade barriers fall and government intrusion in competition recedes. Today, as never before, the need for sound strategies is no longer a luxury but a necessity. To cope with a more competitive environment, more sophisticated analysis is necessary, as is a more rapid translation of plans into action.

The pioneering work on which many modern strategy ideas rest, took place at the Harvard Business School in the early 1960s, led by Kenneth R. Andrews and C. Roland Christensen: At the time when management thinking was oriented toward individual functions such as marketing, production and finance, Andrew and Christensen identified a pressing need for a holistic way of thinking about an enterprise. They articulated the concept of strategy as a tool for doing so. Andrews and Christensen saw strategy as a unifying idea that linked together the functional areas in a company and related its activities to its external environment. Formulating strategy in this approach involved a juxtaposition of the company's strengths and weaknesses and the opportunities and threats presented by its environment (Montgomery and Porter, 1991, p 7).

As presented in Figure 1, the central concept in this early work was the notion of fit between the unique capabilities of a company and the competitive requirements of an industry that distinguished it from others. The challenge for management was to choose or create an environmental context where the company's distinctive competence and resources could produce a relative competitive advantage. This strategy then would be actualized through a consistent effort that coordinated the firm's goals, policies and functional plans (Montgomery and Porter 1991). 
Figure1. Schematic Development of Economic Strategy

\begin{tabular}{|l|}
\hline ENVIROMENTAL \\
CONDITIONS \\
AND TRENDS \\
Economic \\
Technical \\
Physical
\end{tabular}

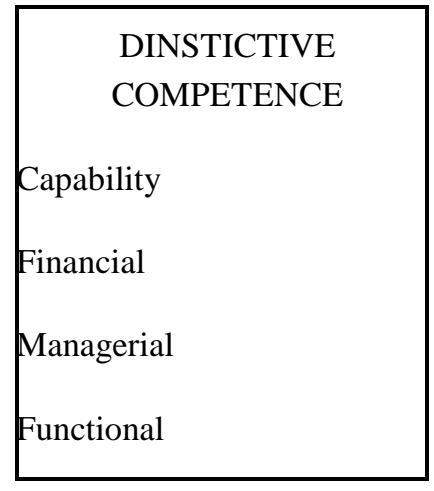

\begin{tabular}{|} 
ENVIROMENTAL \\
CONDITIONS \\
AND TRENDS \\
Economic \\
Technical \\
Physical
\end{tabular}

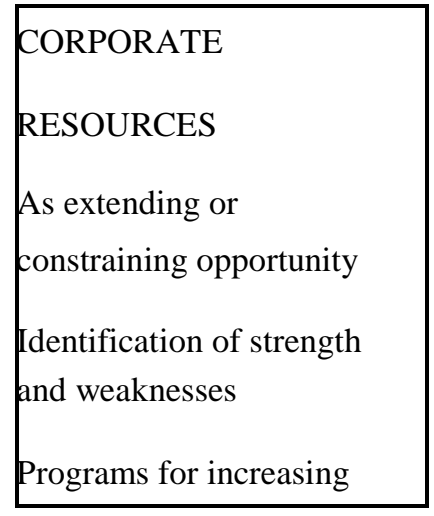

Evaluation to determine best match of opportunity and resources

CHOICE OF PRODUCTS AND MARKETS

Source: Montgomery and Porter 1991

Another important milestone in history of strategic management is the 1962 publication of Chandler's "Strategy and Structure". In formulating a thesis to summaries his findings, Chandler (1962) found it convenient to define two terms, strategy and structure: The thesis that different organization forms result from different types of growth can be stated more precisely if the planning and carrying out of such growth is considered a strategy and, the organization devised to administer these enlarged activities and resources, a structure. According to Chandler, strategy can be defined as the determination of the basic long-term goals and objectives of an enterprise, and the adoption of courses of action and the allocation of resources necessary for carrying out these goals.

The concept of strategy used by Chandler was a handy way of characterizing the relationship among a set of managerial purposes and choices, and was explicitly distinct from a structure (Rumelt, Shendel and Teece, 1994).

Another important strategy concept, "SWOT Analysis" is considered as the basic framework, which shows strategy as the link between the firm and its environment (Grant, 1998).

The distinction between the external environment and the internal environment of the firm is common to most approaches to designing and evaluating business strategies. For example, a common approach is the SWOT framework: Strength, Weaknesses, Opportunities and Threats. This framework distinguishes between two features of the internal environment,

Strength and Weaknesses, and two features of the external environment, opportunities and threats. However, the SWOT framework is handicapped by difficulties in distinguishing strengths from weaknesses and opportunities from threats (Grant, 1998, p 13).

According to Rumelt, Shendel and Teece (1994), strategy is about choices that business makes: Strategic management, often called "policy" or nowadays simply "strategy", is about the direction of organizations, and most often business firms. It includes those subjects of primary concern to senior management, or to anyone seeking reasons for success and failure among organizations. Firms, if not all organizations, are in competition-competition for factor inputs, competition for customers, and ultimately, competition for 
revenues that cover the costs of their chosen manner of surviving. Because of competition, firms have choices to make if they are to survive. Those that are strategic include: the selection of goals, the choice of products and services to offer, the design and configuration of policies determining how the firm positions itself to compete in product markets (e.g., competitive strategy), the choice of an appropriate level of scope and diversity; and the design of organization structure, administrative systems, and policies used to define and coordinate work. It is a basic proposition of strategy field that these choices have critical influence on the success or failure of the enterprise, and that they must be integrated. It is the integration (or reinforcing pattern) among these choices that makes the set a strategy (Rumelt, Shendel and Teece, 1994, p 9).

According to Buzzel and Gale (1987), strategy is defined as the policies and key decisions adopted by management that have major impacts on financial performance. These policies and decisions usually involve significant resource commitments and are not easily reversible.

According to Porter (1994), there are three essential components of strategy. The first is that a company develops and implements an internally consistent set of goals and functional policies that collectively define its position in the market. Strategy is seen as a way of integrating the activities of the diverse functional departments within a firm, including marketing, production, research and development, procurement, finance, and the like. An explicit and mutually reinforcing set of goals and functional policies is needed to counter the centrifugal forces that lead functional departments in separate directions. Strategy, in modern language, is a solution to the agency problem that arises because senior management cannot participate in or monitor all decisions and directly ensure the consistency of the myriad of individual actions and choices that make up a firm's ongoing activities. If an overarching strategy is well understood throughout the organization, many actions are obviously ruled out and individuals can devise their own ways of contributing to the strategy that management would be hard pressed to replicate.

The second component is that this internally consistent set of goals and policies align the firm's strength and weaknesses with the external (industry) opportunities and threats. Strategy is the act of aligning a company and its environment. That environment is subject to change, as are the firm's own capabilities. Thus, the task of strategy is to maintain a dynamic, not a static, balance. (Porter, 1994, p 426). The, third component is that a firm's strategy be centrally concerned with the creation and exploitation of its so-called distinctive competences, the unique strengths that make possible its competitive success (Porter, 1994, p 426).

According to this analysis, components of successful strategy can be summarized as shown in the figure 2 .

Figure 2. The common elements of successful strategies

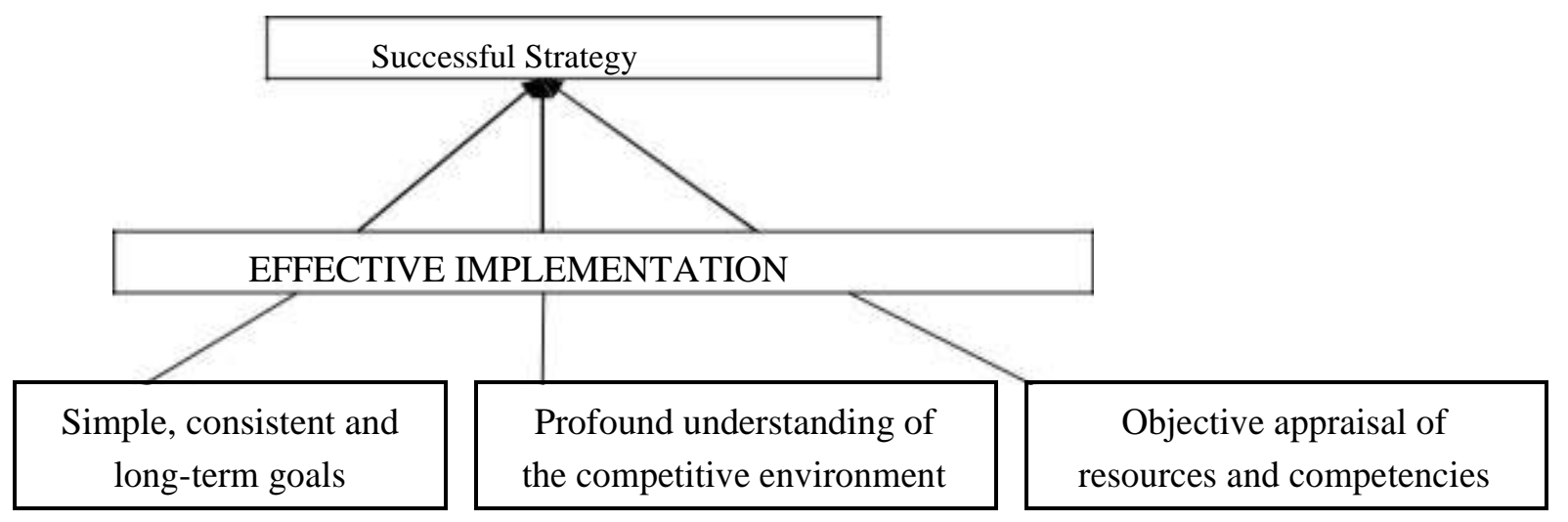

Source: Porter, 1994

An important implication of the firm-strategy-industry environment framework is the concept of strategic fit. For a strategy to be successful, it must be consistent with the firm's goals and values, with its external environment, with its resources and capabilities, and with its organization and systems. Lack of consistency between the strategy pursued by a firm and its external and internal environment is a common source of failure. (Grant, 1998) 
Figure 3. Strategic Fit

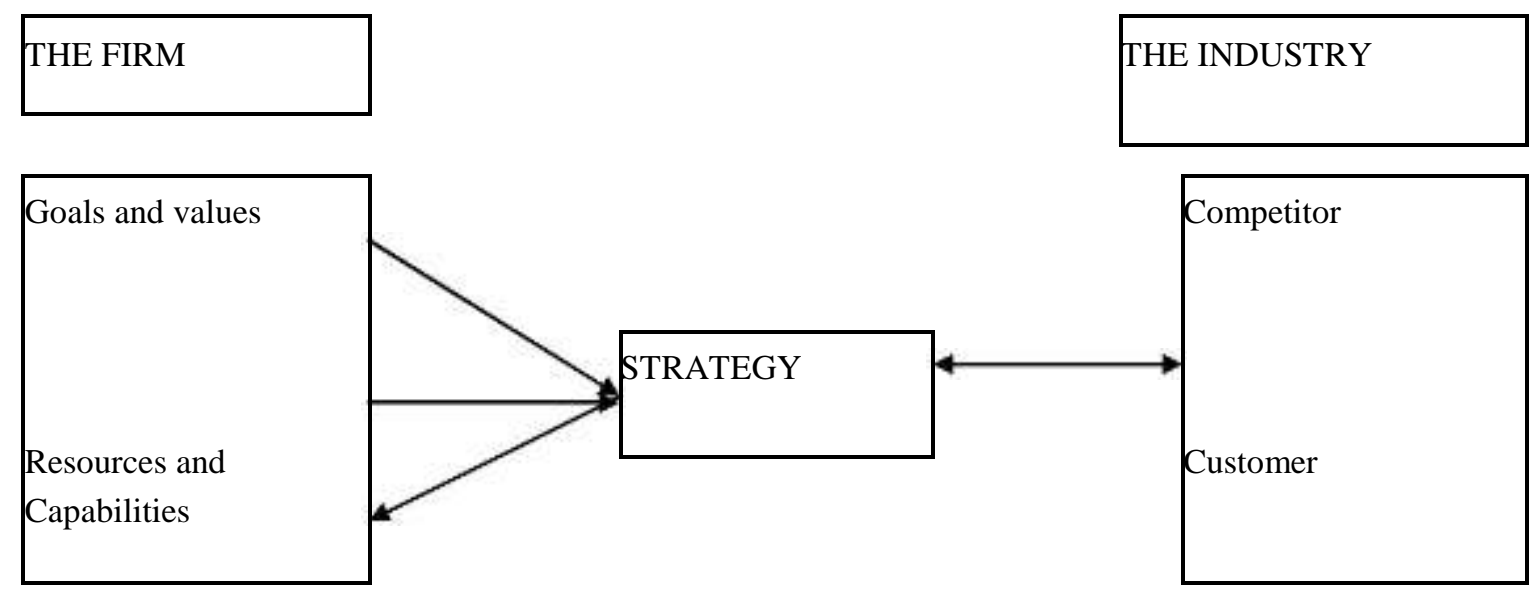

Source: Grant, 1998

\section{Corporate Versus Business Strategy}

As the focus of strategic management has shifted from planning processes to the quest for profit, so the theoretical foundations of the field have been driven by analysis of sources of profit and the factors that result in differences in profitability between firms.

If we accept that the fundamental goal of the firm is to earn a return on its capital that exceeds the cost of its capital, what determines the ability of the firm to earn such a rate of return? There are two routes. First the firm may locate in an industry where favorable industry conditions result in the industry earning a rate of return above the competitive level. Second, the firm may attain a position of advantage vis-a-vis its competitors within an industry allowing it to earn a return in excess of the industry average.

If we accept that the fundamental goal of the firm is to earn a return on its capital that exceeds the cost of its capital, what determines the ability of the firm to earn such a rate of return? There are two routes. First the firm may locate in an industry where favorable industry conditions result in the industry earning a rate of return above the competitive level. Second, the firm may attain a position of advantage vis-a-vis its competitors within an industry allowing it to earn a return in excess of the industry average.

Figure 4. Corporate Versus Business Strategy

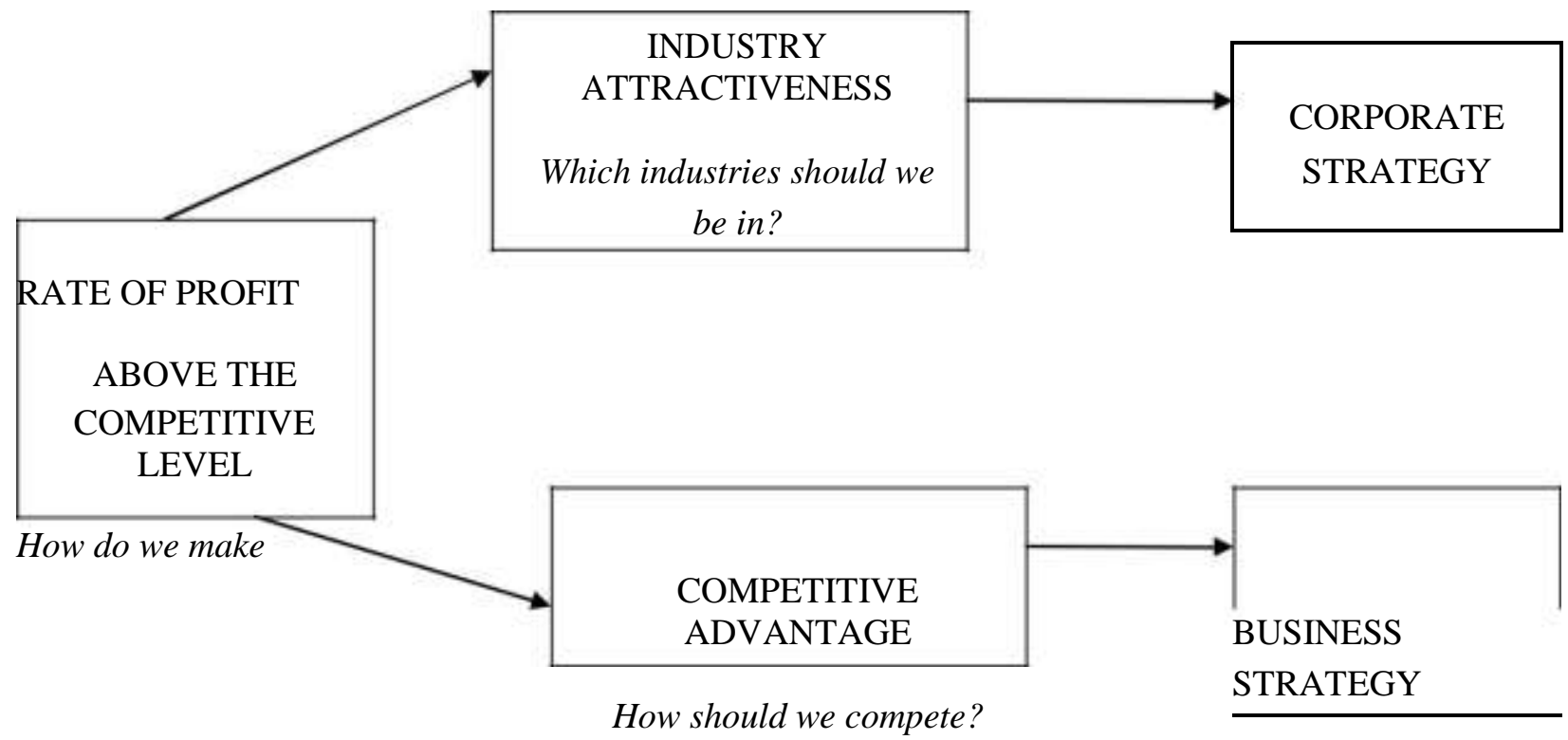

Source: Grant, 1998

These two sources of superior performance define the two basic levels of strategy within an enterprise: corporate strategy and business strategy. Corporate strategy defines the scope of the firm in terms of the industries and markets in which it competes. Corporate strategy decisions include investment in 
diversification, vertical integration, acquisitions, and new ventures; the allocation of resources between the different businesses of the firm; and divestments (Grant, 1998, p19).Business strategy is concerned with how the firm competes within a particular industry or market. If the firm is to prosper within an industry, it must establish a competitive advantage over its rivals. Hence, this area of strategy is also referred to as competitive strategy (Grant, 1998)

\section{Competition, Strategy and Performance}

Since 1970s, researchers have tried to explain three concepts "competition", "strategy" and "performance" which are linked to each other. Before going into details of the history of strategic management, I would like to summarize an interesting article by Bruce D. Henderson. In his article "The Origin, of Strategy", Bruce D. Henderson (1989) draws on Darwin to illuminate the competitive process. Henderson argues that no two firms coexist if they make their livings in identical ways. He frames the problem of strategy as a continued struggle to distinguish a company from its rivals. Competition existed long before strategy. It began with life itself. The first one-cell organisms required certain resources to maintain life. When these resources were adequate, the number grew from one generation to the next. As life evolved, these organisms became a resource for more complex forms of life, and so on the food chain. When any pair of species competed for some essential resource, sooner or later one displaced the other. In the absence of counterbalancing resources that could maintain a stable equilibrium by giving each species an advantage in its own territory, only one of any pair survived (Henderson, 1989, p 3).

According to Henderson (1989), business and biological competition would follow the same pattern of gradual evolutionary change except for one thing. Business strategists can use their imagination and ability reason logically to accelerate the effects of competition and the rate of change. In other words, imagination and logic make strategy possible. Without them, behavior and tactics are either intuitive or the result of conditioned reflexes. But imagination and logic are only two of the factors that determine shifts in competitive equilibrium. Strategy also requires the ability to understand the complex web of natural competition.

Henderson's (1989) proposition is that, strategy is a deliberate search for a plan of action that will develop a business's competitive advantage and compound it. For any company, the search is an iterative process that begins with a recognition of where you are and what you have now. Your most dangerous competitors are those that are most like you. The differences between you and your competitors are the basis of your advantage. If you are in business and are self-supporting, you already have some kind of competitive advantage, no matter how small or subtle. Otherwise, you would have gradually lost customers faster than you gained them. The objective is to enlarge the scope of your advantage, which can happen only at someone else's expense. Unless a business has a unique advantage over its rivals, it has no reason to exist According to Henderson again, strategic competition compresses time. Competitive shifts that might take generations to evolve instead occur in a few short years

Henderson (1989) presented the basic elements of strategic competition as follows: (1) ability to understand competitive behavior as a system in which competitors, customers, money, people, and resources continually interact; (2) ability to use this understanding to predict how a given strategic move will rebalance the competitive equilibrium; (3) resources that can be permanently committed to new uses even though the benefits will be deferred; (4) ability to predict risk and return with enough accuracy and confidence to justify that commitment; and (5) willingness to act.

\section{History of Research On Strategy And Performance}

Attempts to understand and test the connection between strategy and performance began in the 1970s. In this work, three streams ought to be highlighted. One, centered at Harvard and following on Chandler, generated and tested propositions about corporate growth and diversification strategies. A second, focusing on business strategies, began with the brewing studies at Purdue. The third also at Harvard, used an industrial organization economics perspective to study business strategy, and culminated in Michael Porter's work on analyzing competitive strategy and competitive advantage.

The brewing studies done in the early 1970s at Purdue examined the strategies and performance of major U.S. brewers over time. Their goal was to explore the proposition that performance was a function of strategy and environment. The brewers were chosen because they represented a group of mostly undiversified firms, and because, due to product taxation and heavy regulation, good data were available for representing the constructs (i.e., strategy and environment) and functional form of the relationship.

The brewing study results (Hatten and Schendel, 1977; Hatten, Schendel, and Cooper, 1978), were generally consistent with the notion that strategy, in addition to "environment", mattered, so that a "better" strategy, 
relative to competitors, was associated with better performance. The studies also revealed the considerable heterogeneity in strategy and performance that

can exist within a single industry; the differences were far greater than was generally presumed in industrial organization economics and, indeed in most management and strategy thinking. These differences led to very interesting research on strategic groups and to further explanations of performance differences based on concepts of competitive advantage.

The brewing studies demonstrated that the strategy construct could be represented by measurable variables, and that empirical evidence supported the usefulness of the strategy construct itself. What had been derived on the basis of experiential, inductive methods had been supported by more objectives, deductive methods of research. This represented a new departure in Research philosophy for the field in ways that were more significant than the findings themselves (Rumelt, Shendel and Teece, 1994, p 22).

At about the same time as the brewing studies, enthusiasm for Chandler's historical work had inspired further interest in empirically demonstrating a relationship between growth strategy, organization form and the expected performance of the enterprise. This work led ultimately important findings concerning the forms of diversification that improved performance and those that did not. Wrigley (1970), working under Bruce Scott, did the first work in trying to classify diversification strategies. Other dissertation work followed, conducted in a variety of national economies: Channon (1973) studied the United Kingdom, Pavan (1972) studied Italy, Thanheiser (1972) studied Germany and Pooley-Dias (1972) studied France. Rumelt (1974) pushed this stream of work even further, contributing more discriminating measures of diversification and testing the impact of diversification strategy and organizational structure on performance. Like the brewing studies, this work was at least as significant for introducing new methodological approaches to the field as for its findings. (Rumelt, Shendel and Teece, 1994)

In a third major departure for the studies of the relationship of performance and strategy, Porter (1980) imported into the strategy field the concepts developed over the years in industrial organization (IO) economics. Using a large number of case studies as a factual base, Porter employed IO concepts concerning market power and profitability to build a general, cross sectional framework for explaining individual firm performance. Until Porter, firms in strategic management had been seen as adapting to general, even rather vague environments. Porter's "Five Forces" framework substituted a structured, competitive economic environment, in which the ability to bargain effectively in the face of an "extended rivalry" of competing firms, customers, and suppliers determined profit performance. By making managerial choice in an explicitly economic environment the focal point of analysis, Porter succeeded in turning 10 economics on its head. Its traditional role was to identify socially wasteful sources of "monopoly" profits, but Porter instead used the framework to define and explain the strategies available to firms in their quest for survival and profit. Drawing on his extensive case study research, he catalogued, described, and discussed a wide range of phenomena that interfered with free competition and thus allowed abnormal returns, and he suggested how their interaction and relative importance varied across contexts.

Porter's work opened an important bridge to 10 economics across which traveled more than the StructureConduct-Performance paradigm he employed himself. The "Chicago" critique of traditional entry barrier theory, which supported the alternative view that high profits were returns to specialized, high-quality resources or capabilities, became an important inspiration for the resource-based theory of the firm. (Rumelt, Shendel and Teece, 1994, p 23)

Some firms simply do better than others, and they do so consistently. Indeed, it is the fact of these differences that was the origin of strategy concept. According to standard neoclassical economics, competition should erode the extra profits earned by successful firms leaving each firm just enough to pay factor costs. On the other hand, empirical studies show that if you do well today, you tend to do well tomorrow; good results persist.

As Rumelt (1991) notes, in addition to these broad perspectives developed within the field during 1980s, strategy scholars dramatically increased their use of economic theory and their sophistication in doing so, as the examples that follow indicate. The event study methods of financial economics were used to investigate strategic and organizational change as well as the strategic fit of acquisitions. New security-market performance measures were applied to old questions of diversification and performance, market share and performance, as well as other new areas of inquiry. Transaction cost viewpoints on scope and integration were adopted and new theories of the efficiency of social bonding were advanced. Studies of innovation began to use the language of logic of economic rents and appropriability, and research in venture capital responded to the agency and adverse selection problems characteristics of that activity (Ramadani and 
Gerguri, 2011; Gerguri et al., 2013; Ramadani et al., 2013). Agency theory perspectives have been used in the study of firm size, diversification, top management compensation, and growth. The new game-theoretic approach to industrial organization has informed studies of producer reputations, entry and exit, technological change, and the adoption of standards.

In looking back, the purpose has been to understand real-world phenomena and establish a base for making useful prescriptions. For the first time, basic disciplines of the social sciences, especially economics, have been linked with practical issues involved in managing the firm. What began in the 1960s as rather simple concepts of strategy intended to give insight into the phenomena described in cases has evolved into a serious search for intellectual foundations with explanatory and predictive power.

According to Rumelt (1991), the single most significant impact of economics in strategic management has been to radically alter explanations for success. Where the traditional frameworks had success follow leadership, clarity of purpose, and a general notion of fit between the enterprise and its environment, the new framework focused on the impediments to the elimination of abnormal returns. Depending upon the framework employed, success is now seen as sustained by mobility barriers, entry barriers, market preemption, asset specificity, learning, ambiguity, tacit knowledge, no imitable resources and skills, the sharing of core competences, and commitment. In parallel with this, success can be achieved in many ways and through the pursuit of many different strategies. For example, firms often seek to gain major market share positions in attractive industries to enhance their market power. Similarly, firms that are concerned about the long run viability of their current markets will view diversification strategies that reduce their reliance on those markets. Although the compositions of a firm's portfolio of businesses may exert considerable influence on its performance, a firm's overall success will almost certainly be influenced by the effectiveness of its businesses relative to the effectiveness of their rivals. If, when compared with their rivals, a firm's businesses achieve 'the greatest output for the least input', then these businesses are likely to enjoy a considerable advantage over their less competitive rivals.(Stimpert and Duhaime,1997, 565).

Below, three important frameworks explaining the linkage between competition, strategy and performance are presented. These frameworks are:

1. Industrial Organization Paradigm

2. The PIMS Competitive Strategy Paradigm

The Dynamic Theory of Strategy by Michael Porter

\section{Industrial Organization Paradigm}

According to Shepherd (1997), the core issues in industrial organization are as follows:

1. All firms seek higher market shares in order to gain higher profits.

2. When these firms' struggles hold each other in check, effective competition exists. It yields low costs, low prices, rapid innovation and wider profits.

3. If one or several firms come to dominate, competition may be ineffective. The market power causes higher prices and restricted

output, and it imposes social costs: inefficiency, slower innovation, unfair shifts of income and wealth, reduced freedom of choice, and still others.

4. These monopoly costs may be offset, if there are large economies or superior performance by the dominant firms.

The main pattern of cause and effect is illustrated in Figure 5. 
Figure 5. Industrial Organization Paradigm

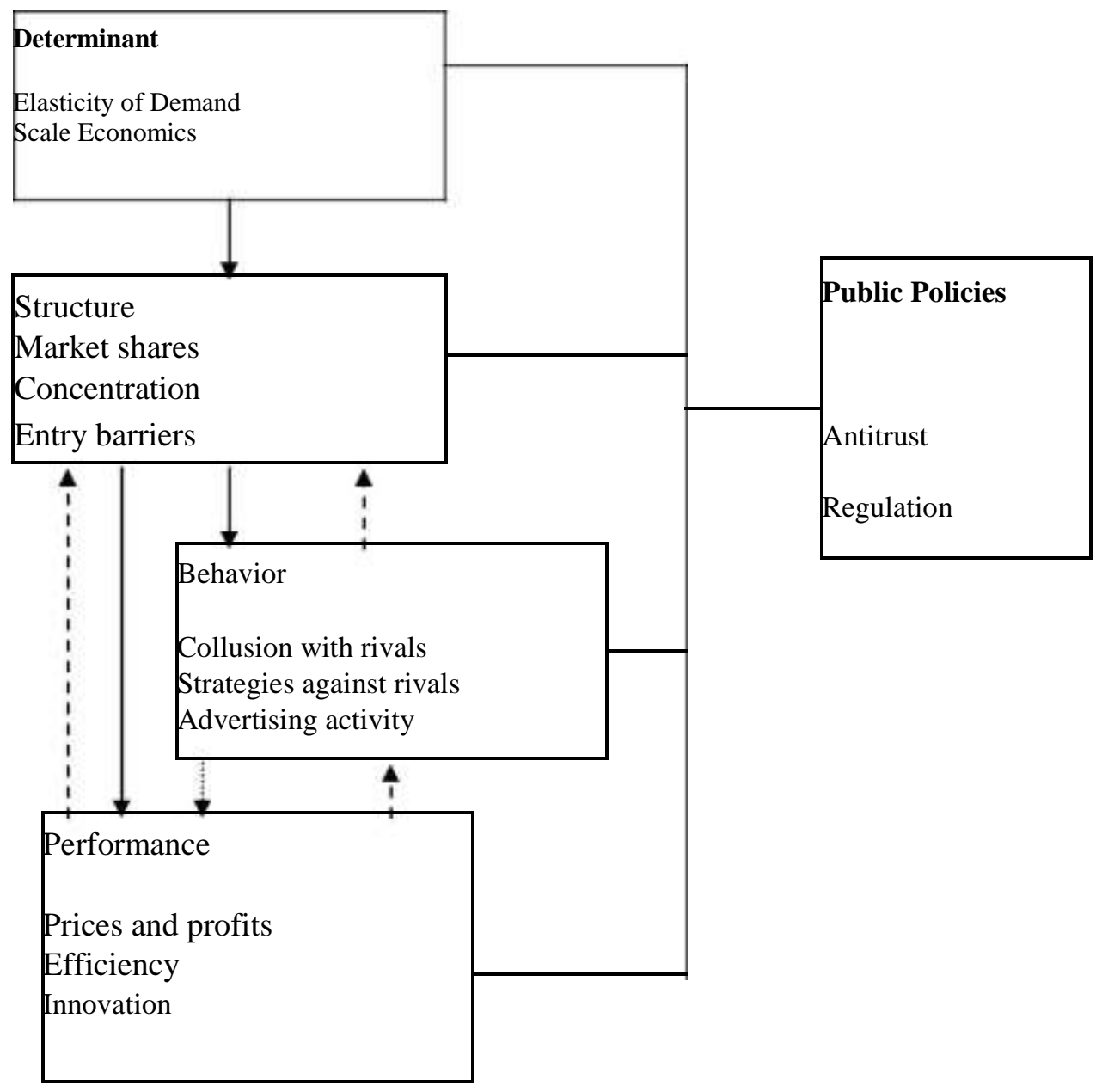

Source: Shepherd, 1997

The causation flows mainly downward, as illustrated by the thick arrows. One leading dominant firm may dominate. If there is a tight oligopoly with several leading firms, they may compete strongly or instead collude with each other some or much of the time. A more concentrated structure therefore tends to encourage market power and its effects. (Shepherd, 1997)

A reversed causation can occur also or instead. It is illustrated by the thinner dashed arrows pointing up from performance to structure. For example, a firm that is superior in efficiency or innovation so that it obtains high profits will generally increase its market share. Therefore, its performance will affect the market's future structure. Mainstream researchers have always recognized this alternative causation, but logic and business experience have strongly suggested that the causation usually flows mostly downward. (Shepherd, 1997, p 6)

Industrial Organization Paradigm emphasizes the importance of market structure and industry on firm profitability. It emphasizes such factors as, market concentration, entry barriers etc.

\section{The PIMS Competitive Strategy Paradigm}

Since 1972, the PIMS (Profit Impact of Market Strategy) Program, working with an extraordinary database of 450 companies and 3,000 business units for periods that range from 2 to 12 years, has developed a set of principles for business strategy.

The central theme of their study is to relate business strategies to performance by studying past experience. The use of PIMS to explore the general relationship between strategy and performance is accepted worldwide as a proven method to produce greater effectiveness for individual firms and the economy as a whole. PIMS take into account three kinds of information: market conditions, competitive position, and financial and operating performance. PIMS explores many possible dimensions of strategy and market environment, such as investment intensity, product or service quality, labor productivity, and vertical integration, all of which have powerful effects on business performance. 
According to Buzzell and Gale (1987), business performance depends on three major kinds of factors: the characteristics of the market in which a business competes, the business's competitive position in. that market place, and the strategy it pursues. The linkages among these factors are summarized below. The arrows in the diagram are meant to indicate that each of the three classes of performance influences has a direct impact on results, and each interacts with the others. Thus, in the short term, strategy is constrained by competitive position and by market structure conditions. Over time, competitive position is shaped by past strategies and by performances, and each of these contributes to changes in market structure.

Figure 6. The PIMS Competitive Strategy Paradigm

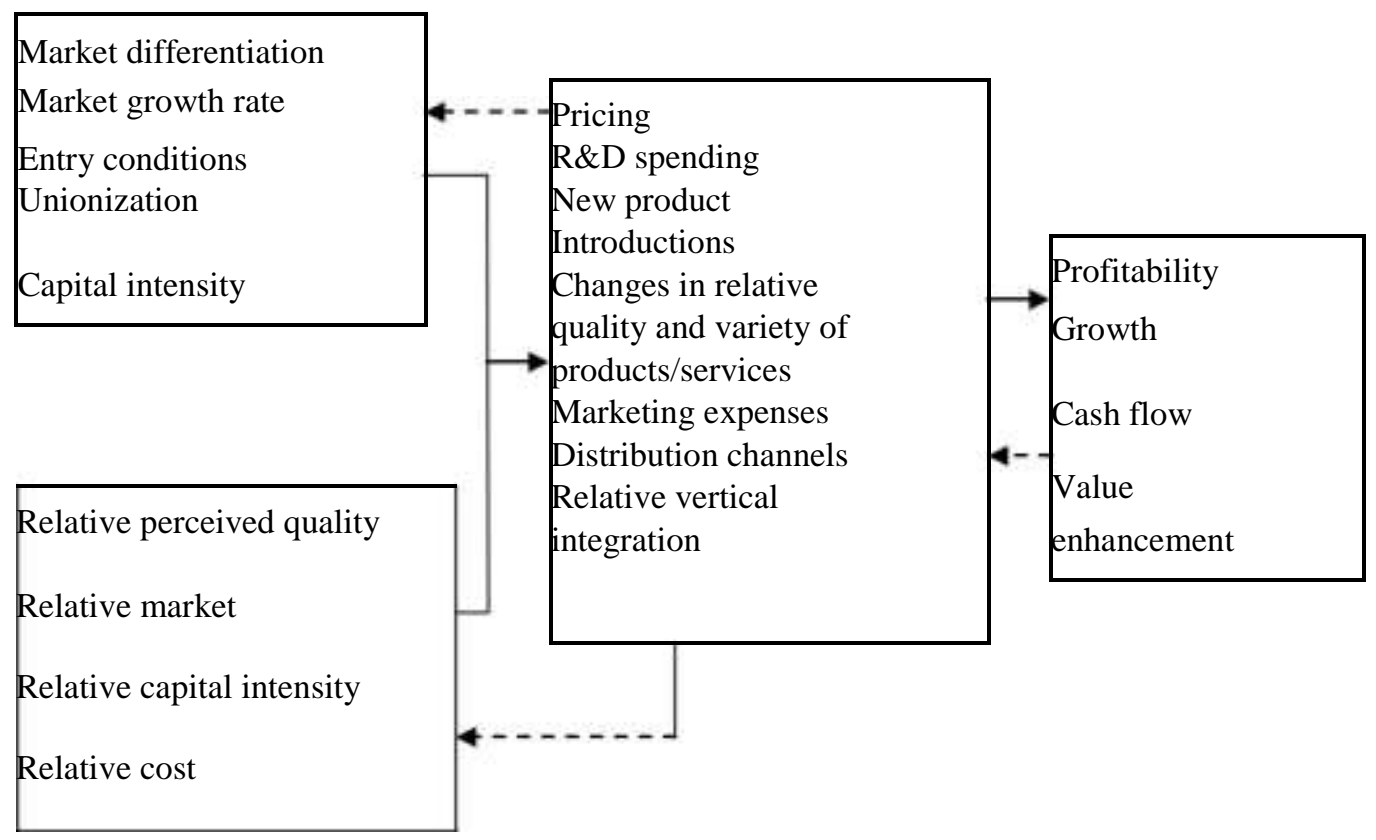

Source: Buzzell and Gale, 1987

Buzzell and Gale (1987) do not claim that the PIMS Competitive Strategy Paradigm includes everything that affects business performance. Profitability, growth, and other dimensions of performance are also affected by such things as inventory valuation methods and by conditions specific to a particular industry or company-such as regulatory changes, swings in currency exchange rates, or labor disputes. But the general, measurable factors included in Figure 2.6 explain most of the variations in performance among business units. The PIMS Competitive Strategy Paradigm incorporates ideas from several important research traditions and viewpoints:

$\square$ The notion that differences in market structure has been explored in depth by scholars in industrial organization economics. As mentioned earlier, these economists traditionally have focused on explaining differences in the average profitability of industries rather than individual business units. Their studies demonstrate the importance of such factors as market growth and barriers to entry.

$\square$ The concept of competitive strategy developed by Harvard Business School, emphasizes the idea that what matters most is an enterprise's position and policies relative to those of competitors.

$\square$ Managers and planning specialists at the General Electric Company developed methods of measuring competitive position and performance that would allow comparisons among diverse product divisions. They also originated the concepts of a business unit and a served market, which are the basic building blocks of strategic analysis in PIMS.

A complex model of competitive strategy is formed by combining all of these ideas.

\section{The Dynamic Theory of Strategy by Michael E. Porter}

In his famous study, Porter (1994) links environmental circumstances and firm behavior to market outcomes. According to Porter (1994), firm success is defined as attaining a competitive position or series of competitive positions that lead to superior and sustainable financial performance. Competitive position is measured, in this context, relative to the world's best rivals. Financial success derived from government intervention or from closing of markets is excluded.

In his research, Porter (1994) noted that, the basic unit of analysis in a theory of strategy must ultimately be a strategically distinct business or industry. While firms can redeploy or share resources, activities, and skills 
across different businesses, the competitive value of such actions can only be measured in terms of some set of rivals delivering a discrete product or service to some set of buyers. Meaningful approaches to corporate level strategy for diversified firms must grow out of a deep understanding of how companies prosper in individual businesses and the role of the corporate office and other sister business units in the process. To explain the competitive success of firms, a theory of strategy is needed that links environmental circumstances and firm behavior to market outcomes. There is a chain of causality for doing so, outlined in Figure 7.

Figure 7. The determinants of Success in Distinct Businesses

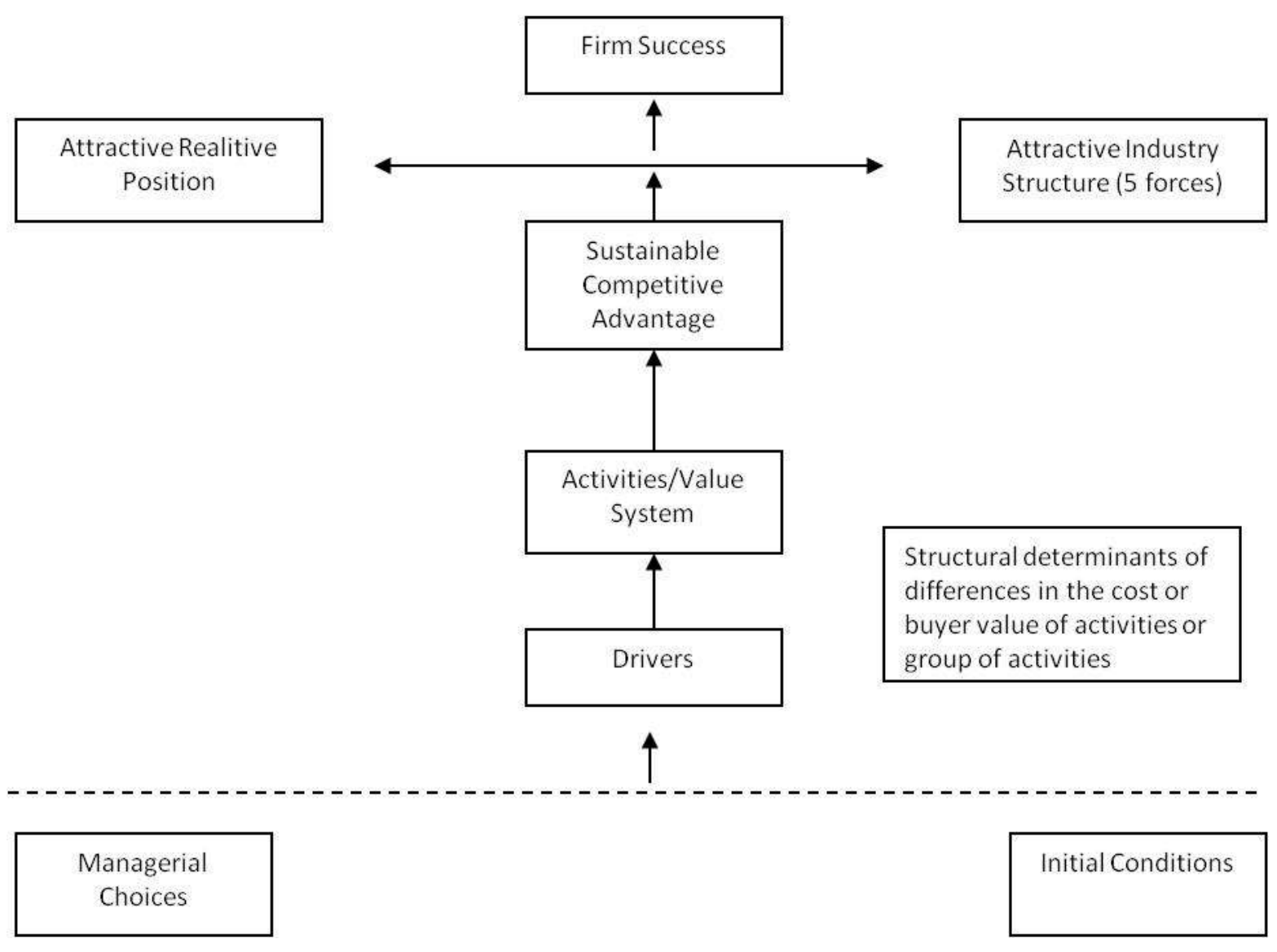

Source: Porter, 1994

At its broadest level, firm success is a function of two factors: the attractiveness of the industry in which the firm competes and its relative position in the industry. Firm profitability can be decomposed into an industry effect and a positioning effect. Some firms' success comes almost wholly from the industry in which they compete; most of their rivals are successful, too! The distinction between industry structure and relative position is important because firms can choose strategies that improve one while harming the other. Firms' actions, by triggering imitation, can positively or negatively influence the structure of an industry without leading to competitive advantage. Ideally however, a firm' s actions trigger responses by rivals, which improve industry structure but simultaneously allow the innovating firm to gain competitive advantage (because rivals' ability to imitate the chosen mode of competition is incomplete). (Porter, 1994, p. 433) Porter (1994) has presented a framework for diagnosing industry structure, built around five competitive forces that erode long-term industry average profitability. This framework has been explored in detail in the next section. The industry structure framework can be applied at the level of the industry, the strategic group (or group of firms with similar strategies), or even

the individual firm. Its ultimate function is to explain the sustainability of profits against bargaining and against direct and indirect competition. Profit differences vis-avis rivals, though, depend on positioning.

According to Porter (1994), if the industry structure is held constant, a successful firm is one with an attractive relative position. An attractive position is, of course, an outcome not a cause. The question is, why and how did the attractive position arise? The answer must be that the firm possesses a sustainable competitive advantage vis-a-vis its rivals. To understand competitive advantage, however, we must 
decompose it. Competitive advantages can be divided into two basic types: lower cost than rivals, or the ability to differentiate and command a premium price that exceeds the extra cost of doing so. Any firm with a superior performance has achieved one or both of these advantages. In other words, superior profitability can only logically arise from commanding a higher price than rivals or enjoying lower costs.

Competitive advantage cannot be examined independently of competitive scope. Scope has a number of dimensions, including the array of product and buyer segments served, the geographic locations in which the firm competes, its degree of vertical integration, and the extent of related businesses in which the firm has a coordinated strategy. Competitive advantage is attained within some scope, and the choice of scope is a central one in strategy. Scope choices can also influence industry structure. (Porter, 1994, p. 434)

These principles, set by Porter, make it clear that the essence of strategy is choice. There is no one best position within an industry, but rather many positions involving choices about the type of advantage sought and the scope of the advantage. Several positions can be attractive in absolute terms, and which is the most attractive to a particular firm may depend on the firm's starting position. It is essential that firm make a choice, however, because there are logical inconsistencies in pursuing several types of advantage or different scopes simultaneously. Also, the firm must stake out a distinct position from its rivals. Imitation almost ensures a lack of competitive advantage and hence mediocre performance.

If competitive advantage within some scope yields an attractive relative position, the question once again is why. In order to address it, we must decompose cost, differentiation and scope. This requires a theory that provides an elemental look at what firms do. Porter's approach to such a theory, and to the sources of competitive advantage, centers around activities (Porter, 1985). A firm is a collection of discrete but interrelated economic activities such as products being assembled, sales people making sales visits, and orders being processed. A firm's strategy defines its configuration of activities and how they interrelate. Competitive advantage results from a firm's ability to perform the required activities at a collectively lower cost than rivals, or to perform some activities in unique ways that create buyer value and hence allow the firm to command a premium price. The required mix and configuration of activities, in turn, is altered by competitive scope. (Porter, 1994, p. 435)

According to Porter (1994), in industries with modest levels of skill and technology, firms can gain advantage solely on the basis of factor advantages such as cheap labor or abundant raw materials. (Such advantages are notoriously unstable, however in a world of globalization, technological change and rapid substitution.) Competitive advantage in more sophisticated industries and industry segment, on the other hand, rarely stems from strength in a single determinant. Sustained success in these industries and segments usually requires the interaction of favorable conditions in several of the determinants and at least parity in the others. This is because advantages in various parts of the diamond are self-reinforcing (Porter, 1994).

This set of frameworks aims to build a careful link between market outcomes and the underlying choices a firm makes in terms of its industry, positioning and configuration of activities. The proper choices depend on a firm's existing position, which can be evaluated systematically via its value chain and drivers. The best strategy also depends on the capabilities and probable behavior of rivals, which can likewise be assessed through their value chain and drivers. Finally, strategy depends on a sophisticated understanding of industry structure.

Ghemawat(1986) proposes the concept of "sustainable advantage". Sustainable advantages fall into three categories: size in the targeted market, superior access to resources or customers, and restrictions on competitors' options. Note that these advantages are nonexclusive. They can, and often do, interact. More of them, it is better.

Lying behind all initial conditions internal to the firm were earlier managerial choices. The skills and market position a firm possesses today are the result of past choices about how to configure activities and what skills to create or acquire. Some of these choices, as Ghemawat's (1991) work among others has emphasized, involve hard-to-reverse commitments (path dependency). Earlier choices, which have led to the current pool of internal skills and assets, are a reflection of the environment that surrounded the firm at the time. The earlier one goes back in the chain of causality, the more it seems that successive managerial choices and initial conditions external to the firm govern outcomes. (Porter, 1994, p. 442

As a summary of what Porter emphasizes, firms inherit positions that constrain and shape their choices, but do not determine them. They have considerable latitude in reconfiguring the value chain with which they compete, expanding or contracting their competitive scope, and influencing important dimensions of their industry environment. Strategy is not a race to occupy one desirable position, but more a textured problem in 
which many positions can be chosen or created. Success requires the choice of a relatively attractive position given industry structure, the firm's circumstances, and the position of competitors. It also requires making all the firm's activities consistent with the chosen position. Below you can find how Porter perceives industry structure and competition in an industry.

\section{Industry structure : The essence of strategy formulation is coping with competition}

In the fight for market share, competition is not manifested only in the other players. Rather, competition in an industry is rooted in its underlying economics, and competitive forces exist that go well beyond the established competence in a particular industry. Customers, suppliers, potential entrants, and substitute products are all competitors that may be more or less prominent or active depending on the industry.(Porter,1979,p 11)

According to Porter (1979), the state of competition in an industry depends on five basic forces, which are diagrammed in Figure 2.8. The collective strength of these forces determines the ultimate profit potential of an industry. It ranges from intense in industries like tires, metal cans, and steel where no company earns spectacular returns on investment, to mild in industries like oil field services and equipment, soft drinks, and toiletries, where there is room for quite high

Figure 8. Forces Governing Competition in an Industry

Threat of entry: There are six major sources of barriers to entry

Economies of scale

Product differentiation

Capital requirements

Cost disadvantages independent of size

Access to distribution channels

Government policy

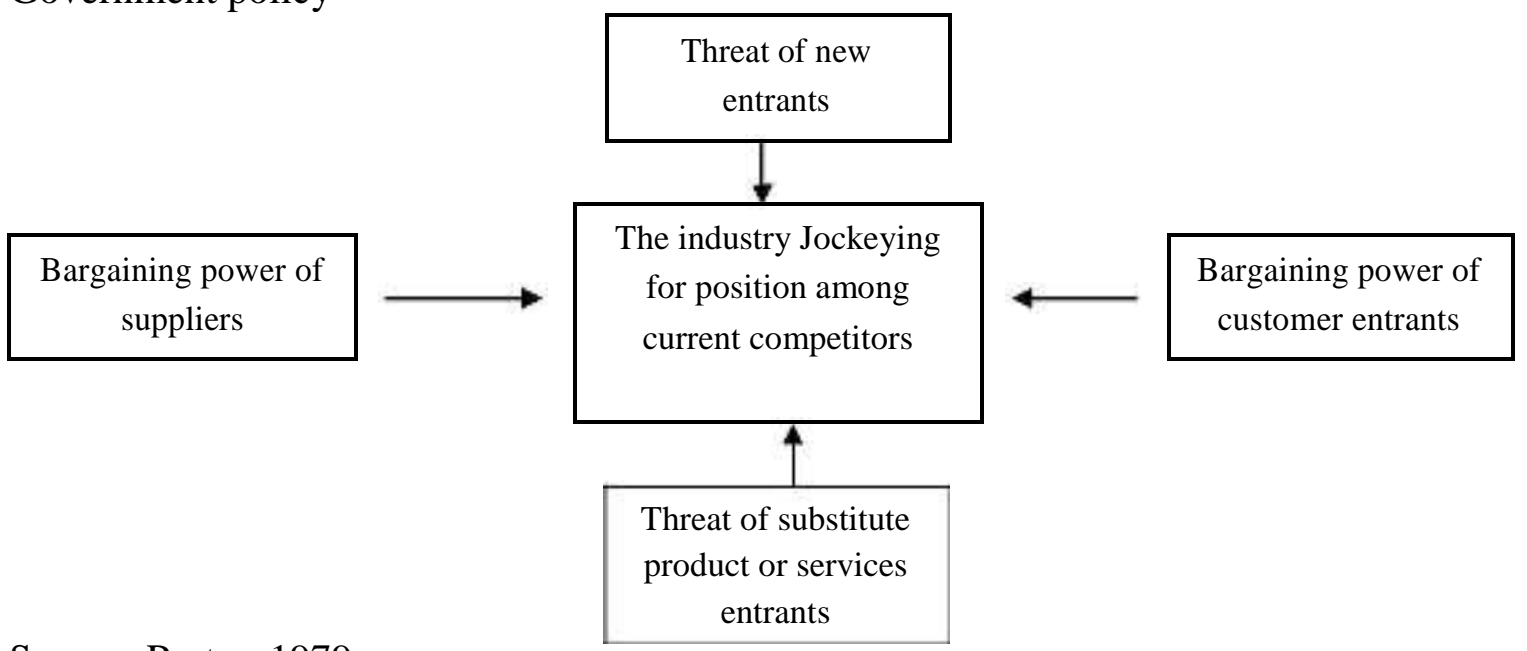

Source: Porter, 1979

In the economists' "perfectly competitive" industry, jockeying for position is unbridled and entry to the industry very easy. This kind of industry structure, of course, offers the worst prospect for long-run profitability. The weaker the forces collectively, however, the greater the opportunity for superior performance. (Porter, 1979, p.11) Whatever their collective strength, the corporate strategist' s goal is to find a position in the industry where his or her company can best defend itself against these forces or can influence them in its favor. The collective strength of the forces may be painfully apparent to all the antagonists; but to cope with them, the strategist must delve below the surface and analyze the sources of each. For example, what makes the industry vulnerable to entry? What determines the bargaining power of suppliers?

Knowledge of these underlying sources of competitive pressure provides the groundwork for a strategic agenda of action. They highlight the critical strengths and weaknesses of the company, animate the positioning of the company in its industry, clarify the areas where strategic changes may yield the greatest payoff, and highlight the places where industry trends promise to hold the greatest significance as either opportunities of threats. Understanding these sources also proves to be of help considering for diversification. 
The strongest competitive force or forces determine the profitability of an industry and so are of greatest importance in strategy formulation. For example, even a company with a strong position in an industry unthreatened by potential entrants will earn low returns if it faces a superior or a lower cost substitute product.

Different forces take on prominence, of course, in shaping competition in each industry. Every industry has an underlying structure, or a set of fundamental economic and technical characteristics, that give rise to these competitive forces. The strategist, wanting to position his company to cope best with its environment or to influence the environment in the company's favor, must learn what make the environment tick.

\section{Why Do Firms Differ?}

Chandler's Scale and Scope (1990) describes in some depth how the different economic conditions, institutions and cultures of the United States, Great Britain and Germany molded the nature of modern manufacturing firms in the first decade of the twentieth century and influenced the industries in which these nations developed special strength. However, there is nothing deterministic about Chandler's description of how the environment shapes firms and influences their performance.

Porter (1980) presents a similar perspective to Chandler. As a summary of the Porter's proposition, environmental influences matter greatly, but the firms have a considerable range of freedom regarding whether, or just how, they will take advantage of the opportunities the environment affords. The firms to some extent molding their own environment.

According to Williams (1994), strategies are inherently self-destructive and thus cannot yield sustainable rents. As the argument goes, any useful strategy attracts imitators, which destroy the rent earning power of that strategy. Thus, strategy (or more precisely any given strategy) cannot matter at least not for long. But in any case, the self-destructive view is incomplete. The reason is uncertainty. The opportunity set in which firms operate is continually being shaped by the economics of search. Firm differences are greater today than they were yesterday. New capabilities, new Coasian boundary conditions, and the character of advanced economies are evolving. Only in the final equilibrium-where no asymmetries existed in capabilities and search -would strategy yield zero rents. In the interim, strategy, although it shares interests with many disciplines, may be distinguished by its interest in rent-seeking behavior.

\section{Conclusions}

Based on this article, the determinants of industry, firm and business financial performance is in the form of measures of individual relationships in models linking various hypothesized causal variables to various performance measures. The causal variables usually describe some combination of elements of the environment, firm strategy and organizational characteristics. This work is found in several disciplines including economics, management, business policy, finance, accounting, management science, international business, sociology and marketing.

A common characteristic of these studies is the inclusion of (1) a dependent variable measuring financial performance; (2) nonfinancial explanatory factors. Financial performance variables include widely used measures embracing levels, growth and variability in profit (typically related to assets, investment or owner's equity) as well as such measures as market value, assets, equity, cash flow, sales, market/book value. Nonfinancial explanatory variables include environmental, strategic, and formal and informal organizational factors.

Present research also continues to affirm the important role industry conditions play in the performance of individual firms. Seeking to explain performance differences across firms, recent studies have repeatedly shown that average industry profitability is, by far, the most significant predictor of firm performance. It is far more important than the extent of a firm's diversification. In short, it is now uncontestable that industry analysis should play a vital role in strategy formation. The reasons for shifting theoretical orientations appear to have been the inability of neoclassical economics to explain intra industry profitability differences, the lack of rigor and inductive nature of case studies, and perhaps a healthy cross-fertilization between fields.

\section{References}

[1] Baucus, D. A., Golec, J. H., Cooper, J. R. (1993). "Estimating Risk-Return Relationships: An Analysis of Measures". Strategic Management Journal. Vol 14. 
[2] Besanko, D., Dranove, D., Shanley, M. (1996), "Economics of Strategy".New York:John Wiley \& Sons Buzzell, R. D., Gale, B.T. (1987). "The PIMS Principles, Linking Strategy To Performance". New York. The Free Press.

[3] Capon, N.Farley J. U.,Hoenig S.(October 1990). "Determinants of Financial Performance: A MetaAnalysis", Management Science. Vol 36.

[4] Chandler, A. D. (1962). "Strategy and Structure". Cambridge MIT Press.

[5] Chandler, A. D. (1990). "Scale and Scope: The Dynamics of Industrial Capitalism". Cambridge.

[6] Harvard University Press.

[7] Cool, K., Diericxx, I., Jemison, D. (1989). "Business Strategy, Market Structure and Risk-Return Rletionships: A Structural Approach". Strategic Management Journal. Vol 10.

[8] Cool, K., Roller, L. H., Lelelux B. (1999). "The Relative Impact of Actual and Potential Rivalry on Firm Profitability in the Pharmaceutical Industry". Strategic Management Journal. Vol 20. Deephouse, D. L. (1999). "To Be Different or To Be the Same? It Is a Question (And Theory) of Strategic Balance". Strategic Management Journal. Vol 20.

[9] Donalson, G. (May-June 1985). "Financial Goals and Strategic Consequences". Harvard Business Review.

[10] Gerguri, S., Rexhepi, G., and Ramadani, V., (2013), Innovation strategies and competitive advantages, Modern Economics: Problems, Trends, Prospects, Vol.8, Issue 1, pp. 10-26

[11] Grant, R. M. (1998). "Contemporary Strategy Analysis". Oxford. Blackwell Publishers Ltd.

[12] Hisrich, R.D. and Ramadani, V. (2017), "Effective Entrepreneurial Management", Springer, Cham.

[13] Hisrich, R.D. and Ramadani, V. (2017), "Entrepreneurial Marketing”, Edward Elgar, Cheltenham.

[14] Hansen, G. S., Wernerfelt, B. (1989). "Determinants of Firm Performance: The Relative Importance of Economic and Organizational Factors". Strategic Management Journal. Vol.10. Henderson, B. D.,(November-December 1989). "The Origin of Strategy". Harvard Business Revi Kmenta, J. (1997). "Elements of Econometrics". The University of Michigan Press.

[15] Lubatkin, M., Chartterjee, S. (1991). "The Strategy-Shareholder Value Relationship: Testing Temporal Stability Across Market Cycles". Strategic Management Journal. Vol. 12.

[16] Markides, C. C. (1995). "Diversification, Refocusing and Economic Performance". Cambridge.

[17] MIT Press.

[18] Mauri, A. J., Michales, M.P. (1998). "Firm and Industry Effects within Strategic Management:

[19] An Emprical Examination". Strategic Management Journal. Vol. 19.

[20] McGivern, M. H., Tvorik, S.J. (1997). "Determinants of Organizational Performance".

[21] Management Decision. Vol 35.

[22] Mehra, A. (1996). "Resource and Market Based Determinants of Performance in the U.S.

[23] Banking Industry". Strategic Mangement Journal. Vol. 17.

[24] Mintzberg, H. (1994). "The Rise and Fall of Strategic Management".U.K. Prentice Hall International Ltd.

[25] Montgomery, C. A., Porter M. E. (1991). "Strategy, Seeking and Securing Competitive Advantage". Boston. Harvard Business School Press.

[26] Nelson, R. R. (1994). "Why do Firms Differ and How Does It Matter?". Boston. Harvard Business School Press.

[27] Porter, M. E. (1994). "Toward a Dynamic Theory of Strategy". Boston. Harvard Business School Press.

[28] Porter, M. E. (March-April 1979). "How Competitive Forces Shape Strategy". Harvard Business Powell, T. C. (1996). "How Much Does Industry Matter? An Alternative Empncal Test". Strategic Management Journal. Vol. 17.

[29] Prahalad and Hamel.(1990)."The Core Competence of Corporation".Harvard Business Revview Roquebert, J. A., Phillips, R. L, Westfall, P.A. (1996). "Markets vs. Management: What Drives Profitability". Strategic Management Journal. Vol. 17.

[30] Ramadani, V., Gerguri, S., Rexhepi, G., and Abduli, S., (2013), Innovation and Economic Development - The Case of FYR of Macedonia, Journal of Balkan and Near Eastern Studies, Vol.15, No. 3, pp. 325-346 
[31] Ramadani, V., and Gerguri, S., (2011), Innovations: Principles and Strategies, Strategic Change, Vol.20, Issue 3-4, pp. 101-110.

[32] Rumelt, R. P. (1991) How Much does Industry Matter?". Strategic Management Journal. Vol 12 Rumelt, R. P., Schendel, D., Teece, D. J. (1991). "Strategic Management and Economics". Strategic Management Journal. Vol. 12.

[33] Rumelt, R. P., Schendel, D., Teece, D. J. (1994). "Fundamental Issues in Strategy: A Research Agenda". Boston. Harvard Business School Press.

[34] Schmalensee, R. (1985). "Do Markets Differ Much?". American Economic Review. Vol. 75. Schwalbach, J. (1991). "Profitability and Market Share: A Reflection on the Functional Relationship". Strategic Management Journal. Vol 12.

[35] Shepherd, W. G. (1997). "The Economics of Industrial Organization". New Jersey. Prentice Hall. Stimpert, I., Duhaime, C. (Jun 1997). "Seeing the Big Picture: The influence of Industry, Diversification, and Business Strategy on Performance". Strategic Management Journal. Vol 40. Taylor, P., Lowe, J. (1995). "A Note on Corporate Strategy and Capital Structure". Strategic Management Journal. Vol. 16.

[36] Wemerfelt, B., Montgomery C.A. (March 1988) "Tobin's q and the Importance of Focus in Firm Performance". American Economic Review. 249

[37] Williams, J. (1994). "Strategy and Serach For Rents: The Evolution of Diversity Among Firms". Boston. Harvard Business School Press. 